\title{
Transpersonal Ether: personhood, family and religion in modern societies
}

\author{
Luiz Fernando Dias Duarte \\ Museu Nacional, Universidade Federal do Rio de Janeiro, Rio de Janeiro/RJ, Brazil \\ Rachel Menezes Aisengart \\ Instituto de Estudos em Saúde Coletiva, Universidade Federal do Rio de Janeiro, \\ Rio de Janeiro/RJ, Brazil
}

\begin{abstract}
This article consists of a theoretical review of the conjunction between lived experience of family belonging and religious encompassment in modern societies, resorting to data resulting from a comparative study of personhood, family and religion in urban Brazil, concentrated in a network of upper social strata and in a medical context of palliative care. In both contexts people move in what may be called a "transpersonal ether", a complex enmeshing of personhood in kinship and religious experiences that far exceeds the limits of the rational, autonomous, units privileged by hegemonic scientific knowledge and individualistic ideology. Our interest is to contribute to the understanding of the processes and characteristics of the "extended self" in general modern conditions and to explore the circumstances in which these dimensions tend to become more explicit, as phenomenological limits and counterparts to the individualization and disenchantment that has characterized Western modernity.
\end{abstract}

Key words: family; personhood; religion; relatedness; palliative care.

\section{Éter transpessoal: pessoa, família e religião nas sociedades modernas}

\section{Resumo}

Fazemos neste artigo uma revisão teórica da conjunção entre a experiência vivida do pertencimento familiar e a do englobamento religioso nas sociedades modernas, com base em dados resultantes de um estudo comparativo sobre pessoa, família e religião no Brasil urbano, concentrado em uma rede dos estratos sociais superiores e em um contexto médico de cuidados paliativos. Em ambos os contextos os sujeitos se movem no que se pode chamar de um "éter transpessoal", um complexo entranhamento da pessoa na experiência religiosa e no parentesco que ultrapassa os limites das unidades racionais e autônomas privilegiadas pelo conhecimento científico hegemônico e pela ideologia individualista. Nosso interesse é o de contribuir para a compreensão dos processos e características do "eu extenso" nas condições modernas em geral e de explorar as circunstâncias em que essas condições tendem a se tornar mais explícitas, como limites e contrapartidas fenomenológicas à individualização e ao desencantamento que caracterizam a modernidade ocidental.

Palavras chave: família; pessoa; religião; relacionalidade; cuidados paliativos. 


\title{
Transpersonal Ether:
}

\section{personhood, family and religion in modern societies}

\author{
Luiz Fernando Dias Duarte \\ Rachel Menezes Aisengart
}

I mean the plastic image of the loved person; not the mere fruit of memory, but the corporeal remembrance, present to all the senses and through all the senses preserved; so that one can never do anything without the sensation of the other, mute and invisible, by one's side (Musil 2001).

Urban elites and middle classes in contemporary Western societies are considered as the main bearers of the individualistic ideology that is so intrinsic to modern cosmology, with its corollaries of family nuclearization, religious disenchantment and self-centered life strategies. Under closer scrutiny it is possible to discern that beneath all this lies a much more complex organization of personhood; one that far exceeds the limits of the highly rationalized, autonomic biopsychological units privileged by hegemonic ideological systems. Social relationships do not develop as juxtaposed concrete individual units but instead in a kind of transpersonal ether, a meshwork of kin ties and sacred links, encompassing the living and the dead, the visible and the invisible, the material and the immaterial.

Our interest here is to discuss the general question of the conceptions of the self beyond individualistic models, to contribute to the understanding of the processes and characteristics of the extended personhood in "modern" conditions. We explore the different circumstances in which these dimensions tend to become more explicit, as phenomenological limits and counterparts to the process of disenchantment that has characterized Western societies since, at least, the 17th century.

Although religion and family tend to be treated sociologically as two distinct dimensions of social life, they are experienced in a common and continuous way, except in the formal, more rarefied, institutionalized levels. In our ethnographic material, it is impossible to extricate the material sensation of family belonging from any of the sundry religious, immaterial encompassments families may cling to. One of the two lines of ethnographic experience dealt with here is the lived sense of family ties and kinship belonging in ordinary life, both in a synchronic and a diachronic dimension, often involved in a religious or a quasi-religious aura. The other line deals with the mingled experience of family belonging and religious encompassment in a specific medical setting. In the first case, we rely on observation and on interviews (life stories) with members of the elites and upper middle classes in Rio de Janeiro concerning their relations with kin and with their family tradition and memories. In the second case, we deal with observation and interviews with health personnel in the context of public palliative medical institutions in Rio de Janeiro and São Paulo, dedicated to the promotion of a good death for terminal patients. In both cases, a deep and complex enmeshing of family and religion prevails. Although the two research foci are empirically distant, they were developed in close connection, as part of a broader anthropological project in Rio de Janeiro, involving researchers from the Museu Nacional/UFRJ, devoted to the understanding of the complex relations between religion, family, health and personhood.

In Brazil, in a very broad sense, Roman Catholic affiliation tends to prevail in middle and higher classes (with Jewish and historical Protestant enclaves). Kardecist spiritualism is nowadays more typical of lower middle classes, although it may pervade upper levels of society in a discreet manner. Afro-Brazilian cults and popular Catholicism used to be the characteristic religious world of lower classes, before the quick 
spread of Pentecostalism in the last four decades (Aubrée, Laplantine 1990; Birman, Leite 2000; Steil 2001). Yet, through all these strata and through all these tense and often transient religious affiliations, family prevails as the unsurpassable realm of transpersonal experience, lay or devout.

Some analyses have stressed pervasive, cross-class continuities in Brazilian religiosity, such as a belief in spirits, whatever their stuff, origins or capacities, and a belief in life after death, on other cosmic levels (Rodrigues 2007; Velho 1991; Maggie 1992). We prefer to consider that kind of beliefs as a sign of a more generalized experience and awareness of relatedness prevailing in Brazilian culture, in contrast with the hegemonic individualized self-image of the metropolitan varieties of Western tradition. That condition might be connected to the "hierarchical", "holistic" dimensions of Brazilian culture, as proposed by Roberto DaMatta (1983), inspired by Louis Dumont's theoretical scheme. Family and religion have been important foci of research regarding that configuration, covering a broad range of specific religious trends or denominations, and an equally broad spectrum of family ideologies and practices (Velho 2001; Salem 2007; Heilborn2004).

Brazilian society, as a version of Latin American or Iberian cultures, is usually considered as a hybrid between traditional forms of relatedness and the modern trends of individualism and rationalism (Morse 1998). Many analyses describe in detail the diverse configurations of that blending through history and across classes. The generalized explicit importance of religion and family, which might seem to be an index of a holistic condition, may coexist with highly sophisticated developments of an allegiance to individualist ideology, as concerns the professional organization of careers, the participation in the public sphere, or the deployment of intellectual and scientific perspectives (Velho 1998).

In a very broad sense, individualism and a certain disenchantment prevail in the upper strata of the society, more akin to the cosmopolitan tendencies of modern thought and behavior (Heilborn 2004). Yet - and this is our focus of interest here - the values of relatedness permeate the projects and the prospects of most members of those strata, even if this occurs in different guises of those prevailing in other classes. Our ethnographic material has been gathered among medical doctors, artists, social scientists, highly placed public officials and professionals; people who adhere to a modern world view, with sophisticated cultural training and a cosmopolitan experience. To describe their experience of life immersed in a transpersonal ether may be a contribution to a wider conscience of the co-presence of these dimensions in most areas of modern Western societies, even those engaged in a most explicitly disenchanted life style.

In fact, contemporary anthropological interpretation of the human condition has consistently stressed the fundamentally relational quality of personal experience, including its most rationalized and individualized versions - even if the abundant ethnographical data on small scale societies still serve as the major source of evidence for such a holist condition (Sahlins 2011; Carsten 2000; Singly 2002; Strathern 1992). Our endeavor here is exactly to contribute to the anthropological awareness of the eminence of transpersonal ties in a Western urban context. The fact that it emerges from a Brazilian context allows for a greater clarity of the phenomenon; challenging the superficial impression that it might be too exotically biased. 


\section{Religion, Family and Personhood - the Universal Challenge of Relatedness}

The concern with participation of discrete beings in some kind of vaster spiritual or moral ether has been constant and consistent in Western social thought. Leaving aside such early - and revealing developments as the theory of "sympathy" in Adam Smith's work (1982), one cannot forget the weight of Lévy-Bruhl's investment in the notion of "participation" (1985), even more explicit in that direction than Durkheim's “authority” (1953) or Mauss' mana (Mauss, Hubert 1973). Drawing from ethnological narratives, those approaches emphasized the intrinsic intensity of social bonds in tribal societies, considered as distinct from the loose knit, rationalized and individualized complex modern societies.

The comparative status of selfhood, briefly sketched by Mauss (1973) in "La Notion de Personne," was tackled again by Louis Dumont, who proposed a new theory of hierarchical opposition alongside a history of individualism, the paradoxical axial ideology of Western culture (Dumont 1972). In his view, the model of a free, equal and autonomous individual emerged and continues to flourish as an ideological device against a universal background of holistic relatedness. It would thus be no surprise to realize that persons everywhere, even in the highly literate upper levels of Western societies, may actually be much more complex and permeable than the discrete pattern could propose.

A similar inspiration has been recurrent in more recent ethnological developments, chastising Western ethnocentric constructions of personhood, kinship (Dumont was also a pioneer in this area) and cosmology. Recent developments of this relativization of individual identity include the proposal of a "partible" and “dividual" person (cf. Strathern 1988 and Gell 1998). Strathern's idea of "mediated exchanges" between people and things or Gell's idea of a "distributed person" might also be useful for the description of modern transpersonal selves.

Marshall Sahlins has recently summarized these trends in a manner most convenient for our purposes. He evokes a list of sources of a broader concept of personhood, one that emphasizes a "mutuality of being", in the sense of "people who are intrinsic to one another's existence" (Sahlins 2011). Categories such as "conjoined existence", "intersubjective belonging", "diffuse enduring solidarity", "transpersonal relations of being and existence", and "mystical interdependence" emerge in quotations from Aristotle, Durkheim or a list of contemporaneous ethnological works'.

The concept of "relatedness", as developed by Janet Carsten (2000), is most akin to Sahlins' endeavor and to Dumont's original criticism of the individualistic ideal of modern person. We consider most convenient to append to it Polanyi's (1957) concept of "embeddedness", so as to further evince an extended sense of self, family and religion. His original proposal, destined to a more considerate historical appreciation of the specific character of economic ideology in modern world, emphasizes the essential holistic embedding of all social phenomena prior to the rationalization implied by modern cosmology. We can thus consider Dumont's universal hierarchical condition as a universal embedding, a vast sense of belonging, of participation, of cosmological mutuality ${ }^{2}$.

The conscience of the limits to the process of disenchantment (or rationalization), secularization and individualization in Western culture has grown in recent years thanks to the evidence of a religious revival (Berger 2001). Contrariwise, the depth of the experience of family belonging remains still largely in the margins of common academic conscience, except there where it is immediately enfolded by religious adherence. The weight of individualistic ideology prevents most elaborations of a lay perception of family embeddedness, in spite of the universal personal testimony of life entanglements (Maître 1996; Singly 2002).

1 Pina Cabral developed a similar concept of "continued identities" to deal with family experience in contemporary Portuguese urban settings (2003). 2 An area of Transpersonal Studies develops in the margins of natural sciences, partly responding to psychologies of altered states of conscience, and apparently unaware of anthropological and sociological analyses. There is an International Journal of Transpersonal Studies, just as a Journal of Transpersonal Psychology and an Association for Transpersonal Psychology, whose website proclaims that "The Association's mission is to promote eco-spiritual transformation through transpersonal inquiry and action." See Hartelius et al. 2013. 
The hegemony of the model of the minimal nuclear family in modern societies does not eliminate the personal feeling of belonging to some kind of wider relational order, even in national and class cultures more exposed to the ideology of individualism³. An imaginary congregation is conjured by the complex of transgenerational bilateral kinship conceived as an ideal, private and intimate corporation of affects and memories. Although an actual network typically exists and may be activated, it depends on the feeling of intimate and personal communion, without which the self tends to detach from effective conviviality, experiencing the former as inauthentic and lacking in intensity.

The experience of belonging is further intensified in periods and conditions that threaten the ordinary course of life, all sorts of crises, but mostly the challenge of severe illness and the risk of death. The liminal condition thus faced involves a reduction of individual self-sufficiency and an intensification of a search for a global involvement. In these circumstances a kind of unified field of belonging comes to the fore, enmeshing family and religion. Life crises are an essential dimension, but they cannot be understood separated from the prevailing national and class cultural emphases, concerning age, gender, generation, normality, deviance and illness. A progressive return to a sense of family belonging is usually associated with marriage, pregnancy and the birth of the first child (or the first grandchild) - with family reproduction in sum. In the extreme opposite condition, severe threats to family life have a similar outcome: crises of all sorts, prolonged illness and ageing (mostly in terminal conditions) tend to reinforce the sense and challenge of belonging.

There are relevant differences in such processes according to social class or status groups: as a rule, a more permanent sense of belonging tends to prevail among working classes and traditional upper classes, for quite different reasons. Moral ties, in the first case, related to strong shared immediate experiences and tight local solidarity; moral ties too, in the second, but related to strong shared traditions and common economic interests.

Other relevant difference is the explicit adherence to formal religious beliefs and cults, which account for the manner and style the new sense of belonging may assume. In any case three essential emotional dimensions give shape to the new condition: communion, reverence and intensity (cf. Duarte 2007). Although they are usually equated with religious affiliation, they are also characteristic of the intersubjective ether one does bathe in when family belonging prevails. Communion as against the ordinary sense of autonomic identity our culture endorses; reverence as against the plain sense of a shallow equality among people, either contemporary or from the past; intensity - finally - as against the ordinary course of life, flowing according to external, clock time. What is usually called a conversion is a complex turn into an altered state summoned by these unusual conditions $s^{4}$.

The phenomenology of family transpersonal experience depends also on the relative weight of two axes: the transgenerational or historical one and the parallel or contemporaneous one. The senses of communion and reverence tend to concentrate on one of the axes, in detriment of the other, according to certain circumstances. In a very general way it is possible to ascertain that parallel belonging prevails in positive circumstances - of a new birth for instance, while the transgenerational one prevails in negative conditions - as in the face of death. But this depends heavily on the moment of the person's life cycle - on parents or grandparents being alive or not, on the extension and nearness of sibling networks, on the existence of

\footnotetext{
3 Sahlins is very explicit about this possibility in modern societies, fearing that the category "dividuality", as used by Marilyn Strathern in contrast to "individuality", might be restricted to "a universal form of premodern subjectivity". In his terms, "partible and relational identities may characterize persons who are not 'dividual' kin persons - but perhaps even bourgeois individuals like us" (2013: 27), or "bourgeois persons are in their intimate kin relationships as 'dividual' as Melanesians” (2013: 28) - our emphases.

4 Our point here, concerning the mingling of religion and family in a transpersonal ether, is not reducible to a matter of external "influence" or "impact" of religious questions and attitudes upon family experience (or the other way round). It is a matter of concomitant and reciprocal institution of a common belonging. See also, on this point, Christiano 2000.
} 
descendants or on the depth of genealogical conscience. Working class people are thus less prone to resort to long range transgenerational links than other classes, where the cult of ancestors may be accrued by material continuities, such as family sacra.

New ways have recently arisen, in which the phenomenology of the extended self in transpersonal settings can be observed. The newest trends in genomics are being put to use to explore and reinforce family ties, particularly in the area of recognition of paternity (cf. Finamori 2012) and personal genomics (cf. Pálsson 2012). The information regarding the intensive recourse in Brazil to genetic analyses to confirm (or disprove) filiation contains precious examples of transpersonal feelings, influences at a distance, mutual belonging, supposedly previous to the material disclosure of real "blood" ties5. Personal genomics has catapulted genealogical fantasies into deep time, thousands of years deeper than European aristocracy could ever trace its roots. This is accompanied by feelings of collective belonging, of some kind of emotional continuity. Bryan Sykes, an important scientist involved in a genetics testing firm, says about the reactions to the definition of one's ancestral "clans": "We look at each other and sense our deep umbilical connection. ... I feel we have something very deep in common" (apud Pálsson 2012: S187).

\section{Transpersonal ties in ordinary life: an inquiry into family and religion in an elite sector of Brazilian society}

The research conducted by Duarte in Rio de Janeiro, among elite and upper middle class groups, as a comparative counterpoint to his original studies about working class culture, concentrated exactly on the relationship between family and religion. The contact with the 17 interviewees was based on an invitation to talk about the relationship with their families; no explicit mention being initially made to religion. Fifteen were selected on a snow-ball strategy starting from a longtime friend of the researcher, a social scientist belonging to a very traditional family, being himself the grandson of a nationally prestigious epidemiologist. These people were thus related among themselves, although in a very loose manner, and only three of them were connected by kinship. The other two were selected from a list of the members of the National Academy of Sciences who lived in Rio de Janeiro, providing they had no evident link with the first network. All the interlocutors - 12 women and seven men - were more than 6o years old, were highly cultivated, and lived comfortably in upper class neighborhoods in Rio or in the nearby towns. The life story of a deceased relative of the researcher was included in the analysis, as it had been retrieved and scrutinized in an article he had recently written about his maternal family (cf. Duarte 2011). Most people were brought up as Roman Catholics, except for two women, who belonged to Jewish families, and for two other who came from a Protestant background (one Presbyterian, the other Anglican). Some of the interviewees made references to spiritualist themes (including the Presbyterian born) and some others were close to New Age culture. With one single exception, they did not see themselves as "religious", strongly influenced as they were by the ideology of laicity and rationalized individualism.

The long interviews (sometimes repeated twice or thrice) revealed spontaneously a rich entanglement of family stories and memoirs with religious (or quasi-religious) themes. In fact, the researcher had been initially surprised with the scarcity of overt religious references in the life accounts, until he realized, as mentioned in a previous work,

5 The imaginary power of the ideology of "blood" has been well described for Western culture, often implying a kind of immaterial agency that reaches far beyond actual social and family bonds: "the voice of blood will always tell". It is a dramatic key often resorted to in Brazilian highly popular TV soap operas. 
"that the recurrent, intense, and almost obsessively reverential tone associated in other contexts with religious experience were, in this social circle, linked to family living, the memory of past family experiences, the fate of close kin and the enveloping feelings of family identity" (Duarte 2007: 2).

The recognition of this "sacred universe", encompassing both family and religiosity, allowed for the attention to a kind of unified field, that gathered the sparse references to official, explicit attention to the conventional religious world together with the ubiquitous reference to thick, encompassing, family and kinship relatedness.

Irene, a lady presenting an intense sense of belonging to her mother's family, highly prestigious and in a slow process of decadence, had harbored in her own house, after the death of the previous generation, a remarkable amount of family heirlooms, that had helped her face a marriage to a member of a very highly placed elite family. The bankruptcy of her husband brought about a state of enduring crisis, resulting in the progressive dispersion of most family treasures and in a sense of doom and malediction she weaved from a series of ominous family stories and personal grievances regarding such and such a relative. A seemingly endless negotiation regarding a long-cherished family estate about to be sold became a source of elaborate nightmares and an excruciating quest for her role in the family novel and the destiny of her own children, until she was able - in her terms - to "desacralize" the link with that revered legacy and subdue the emotional intensity that had always surrounded it. A disposition towards New Age resources is permanent in her life style, including the eventual services of Afro-Brazilian mediums and a recurrent demand for the service of professional astrologists ${ }^{6}$. She had been an outstanding social scientist, with a rich intellectual production, who relinquished her personal career to better attend to family requirements.

A common friend, Victor (a fictitious name, as all here), became a highly esteemed professional artist in spite of his intermittent mental disturbances. He attributes his artistic vein to the influence of his celebrated maternal grand-father, a leading name of Brazilian classical musical scene. "My grand-father is my Holy Ghost", he says; commenting on a painting where he makes the ancestor levitate against a crudely yellow glow. The lurking presence of this prestigious link mediates the negotiations with his family network, in which all sorts of affects and goods circulate intensely.

Arthur is an engineer and the descendant of a major political and professional family. His maternal grand-father had been a scientist with an outstanding role in the modernization of the country. A member of Brazil's old landed aristocracy, he offered a marked contrast with his father, a physician from a family of recent migrants. He explicitly refused to participate in the meticulous cult organized by his mother to her ancestors. This resulted in a constant hesitation between professionalization and dedication to an artistic vocation precociously suppressed by the father. Moving ambiguously among family heirlooms and memoirs, he came to feel haunted by the ghost of his mother, petrified in nocturnal apparitions, resented as a cruel remembrance of a most intense relation, during the long illness that led to his relatively early death.

Alba is a journalist from an old Protestant, very stern and socially very well placed family, abounding in professionals and intellectuals. She had been one among a long series of siblings and resented a certain lack of attention in her childhood. After marriage and the birth of her two children, she moved towards spiritualism; in order to provide "spiritual help" for her children, who seemed frail and unstable to her. She conjured the anxieties felt towards her own family through the typical display of public charity characteristic of Kardecist centers. In her later years, she confided that she felt a sense of strong spiritual continuity between her own deceased mother and her only granddaughter, still in her early years. In her case, the intensity of transgenerational ties equaled that of the contemporary ones; probably thanks to the belief in reincarnation, which allowed for a peculiar balance between past and present. She was the only interviewee to declare an explicit and stable relation with a religious system.

6 The analysis of horoscopes is a frequent aspect of the transpersonal ether: ancestors and relatives have their zodiac signs and astrological charts compared and scrutinized so as to evince personal attachments or antipathies. 
Holding a leading role in the public administration of Rio de Janeiro, Sebastian had grown in a lower middle class family that maintained a spiritualist circle in their own house, around the mediumship of one of his brothers. His relatives used to share their regular dreams concerning the destiny of the dead ones; dreams that were scrutinized in order to evaluate the possibilities of reincarnation and spiritual advancement. Although he did not engage personally in any of those rituals, partly in connection with his adult technical professionalization and personal social ascent, he was quite aware of these diagnoses, as he expected to return to his parents' arms after his death - a feeling he stressed as most soothing and appeasing in the face of old age and recurrent illness. For most of his female relatives the charitable activities of Kardecist centers was concomitant with intense worries concerning the poorer branches of the family, some of whose members were seen as the returned souls of ancestors.

Mario, a prestigious psychoanalyst, described a most peculiar and intense personal concern with his family nebula. He engaged in nightly ritual prayers to some of his predecessors, drawing on his memory of their own attitudes towards family and particularly towards his maternal lineage, which had faced enduring conflictive dramas through many generations, mostly connected with material heritage and the maintenance of family status. He was very keen on caring for his heirlooms and resented heavily having deserted the family estates in his town of origin. A feeling of guilt seemed to emerge regarding the impossibility to restore the past grandeur of the family; much as a fear of a continued malignant action on the part of certain deceased relatives, as a distant yet sensible echo of old feuds and resentments.

An interesting dimension of the previous cases is the constitution of spiritual congregations that complexly overlap family belonging, as found more explicitly among groups influenced by spiritualism. Alba evokes precisely this point when she claims that the link to her granddaughter intensified as a result of discovering her to be the reincarnation of her own mother. In Sebastian's family, the overlapping seemed to be more complex, as in the case described by Mazur (2006) for the family of an Eastern European female medium near Rio de Janeiro where all the members of the network were considered as new incarnations of past relatives, imposing quite elaborate constraints to conventional social exchanges.

The "socio-historical psychoanalysis" proposed by Jacques Maître in his analysis of life history of St. Therese of Lisieux (1996) is also conducive to a greater conscience of the family embedding of the self. Therese's case is particularly revealing of the enmeshing of family and religion: most of her family members were intensely involved with Roman Catholicism and its cult of a Holy Family. The reverence flowed easily between the transcendent and the mundane levels of an intricate relational web7.

The concept of a "family mandate" coined by transgenerational psychoanalysis (cf. Abraham 1987) was employed by Duarte in an analysis of a character of his own upper middle-class family, whose deviant career could be associated to the meanderings of social identity through a series of generations of namesakes. The recurrence of personal names across lineages and generations, frequently associated - as in this case - with godparenthood, may be a meaningful symptom, among others, of the symbolic burdens imposed upon descendants in certain cases. To become a social renouncer, as happened in that instance, may be as clearly a reaction to the cogency of family mandates as the submission to a positive legacy. Domingos remained alone all through his life, entrenched in the family house and surrounded by family heirlooms, all fallen into disrepair, the prey to a kind of obsessive neurosis, eagerly attentive to all the movements of his relatives, to all activities concerning family property, busy in telephone exchange with kin, continuously praying for the living and ordering for masses on behalf of his dead relatives (Duarte 2011).

7 As a negative counterpoint we can find the ethnography by Steil (2006) of a Roman Catholic charismatic circle in Brazil, where exorcism is required to forestall the influence of dead relatives encroached upon people during their stage in the womb. 
Through these brief sketches, drawn out of the life stories elicited during the research, it is possible to trace instances of the generalized "communion" effect prevailing in this dimension of family experience. The inheritance of moral qualities along the transgenerational line was an important topic of concern, either upwards or downwards - as in the cases of Victor or Sebastian. Many edifying stories about the relation between parents and children revealed that some sort of training concerning the ethics of respect and responsibility among relatives (mostly among siblings) was always in action, often supported by references (positive or negative) to family characteristics through time.

This appeal to family memories was reinforced by the omnipresent reference to family heirlooms. These sacra included all sorts of properties and objects, depending on the historical characteristics of each family. The presence - or much lamented loss - of these precious elements of family identity structured long digressions concerning the amount of mana concentrated thereupon, as in the dramatic case of Irene. In such cases, the economic dimension of the properties was inextricable from the moral one; and, in many cases, the efforts to maintain connection with some items were clearly "irrational" from a pragmatic point of view. The submission of the family house (with a good part of family sacra) to Domingos' frankly deviant career presented for the younger generations the effect of a magical cave, immersed in a halo of memoirs (and photos) of the past, embedded in a common web of apotropaic moral lessons.

Both moral and material bases for the cult of family identity are usually ascribed to certain subjects among relatives. Women are generally invested with the role of "memory guardians" (cf. Lins de Barros 1987), authorized priestesses of the adequate propitiatory rituals, such as the collective remembrance of birthdays and commemorative religious functions. They tend to act as fierce keepers or protectors of family sacra, including the up-keeping of family graves, and the promotion of eventual collective meetings in some revered location ${ }^{8}$. The pathos of Arthur and Mario's moral careers was - on the other side - typical of the male members of a family who felt guilty for not having been able to maintain real estate property; male heirs being the entitled guardians of this other, more public, side of the reproduction of a common identity 9

An important point in the organization of the family extensions of the self is the distinction between paternal and maternal kin. Although the official model of Western family stresses the bilateral quality of kinship and proposes a certain equality in the content of "blood" and "genes" arising from both sources, and also in spite of a traditional patrilateral emphasis in the inheritance of names and property, a matrilateral trend seems quite evident as regards the transgenerational flow of moral sentiments and inner identities ${ }^{10}$.

Most of the activities involving the reproduction of a sense of family communion occur imbued with the appropriate reverence regarding the moral and material bonds connecting ancestors, contemporaries and descendants. It was certainly a lighter and more diffuse reverence than the one supposed to reign in official religious precincts and occasions, but it was there nonetheless, perceptible in a change of voice, in a slower pace of the memoirs, devoted to capture and render a displacement of the level of reality. Even the occurrence of a blasphemous attitude to family bonds, as was the case of Arthur in his last days, can be interpreted as part of that pattern - in a kind of "negative cult" (cf. Durkheim 1968).

8 An excellent description of the female role in the reproduction of Western elite families is available in the detailed ethnography of a Mexican family we owe to Larissa Lomnitz and Marisol Perez-Lizaur(1987). The connection between the moral and religious tasks ascribed to the family women in that case present a close parallel with our argument here.

9 In the social milieu studied here there were already some signs of a change in this strict gender role definition; as demonstrate the efforts of Irene to save her family heritage from her husband's debacle. An interesting example of this change, among contemporary Italian industrialist families, can be found in Yanagisako 1979 .

10 The concept of "complementary filiation", proposed by the anthropologist Meyer Fortes, allowed for the recognition of the importance of subordinate matrilineal rights and duties in African patrilineal societies. In many ethnological instances the paramount lineage accounts for official inheritance qualities, while the "complementary" one accounts for covert or marginal powers, such as secrets related to witchcraft (Fortes 1970b). 
In some of the cases studied here the representation and expectation of a re-encounter with one's parents after their death could be explicitly found. This belief was not necessarily based on a religious premise, although it was externalized with great emotion and anxiety.

The respectful attitudes of my aged interviewees towards dead kin were not entirely shared by their young descendants - a point of great anxiety, as if their own future cult might not be assured. In fact, as we have already mentioned, this system of reverence develops alongside the life cycle, becoming particularly intense after the birth of a first child or a first grandchild. Two men in my web of interlocutors were childless; their relational emphases were clearly more horizontal, regarding living relatives and their descendants.

It is clear, in all these cases, that our proposal of a transpersonal ether is inseparable from the recognition of a special intensity surrounding family events, memoirs and sacra. What we have called reverence is the outer expression of a peculiar intensity of inner feelings - for good or bad - when family matters are seriously faced, experienced, or accounted for. If reverence may be presumed in the contrite attitude often characteristic of religious affairs, intensity is more labile and unforeseeable. During the interviews, there were moments in which intensity could be discerned from a series of subtle emotional resources; tears being only the most evident. But intensity is not only a sad disposition; it was also clearly displayed in a joyous key - mostly regarding the life of the descendants, and the inner connection with their sentiments and hopes ${ }^{11}$.

In several occasions people expressed their gratitude to the researcher for having given them the chance to externalize these inchoate feelings in a sustained and systematic way. There was also some concern that the recordings might have stored overly secret, sensitive, serious and important matters - as if fearing them to be defiled in the ordinary profane world.

\section{Transpersonal ties in a palliative care institutional setting}

The research conducted on palliative care in institutionalized medical settings brings another perspective on the theme of transpersonal experience (cf. Menezes 2004, 2006, 2009, 2011; Menezes, Heilborn 2007). One of the circumstances in which Western individuals tend to acknowledge their embedding in extended dimensions of relatedness is the experience of the end of life. The exposure to old age, to long severe illnesses, to disability and curtailment of one's capacities reveals the general dependency on which human life thrives. The approach of death intensifies this conscience to an acute level, leading to changes in the family pattern and roles.

The research was conducted in hospital contexts, organized according to the model of palliative care, destined for patients considered as "terminal" or having "run out of therapeutic possibilities". The palliative care proposal consists in caring for this type of patient up to their last moments, seeking to minimize their discomfort as much as possible, so as to provide "quality of life". Emphasis is placed on the possibility of intense experience. When the disease is considered to be curable, health professionals focus on cure treatments, and the stress is on extending the duration of life. Once resources for controlling the disease have run out, there is a shift in focus: from the disease to the patient; from the prolonging of life to life with intensity and quality. In this change, the family, once seen as a merely supporting actor by the health team, begins to play a fundamental role in care, towards producing a "good death". The key words

11 It is possible to speak of a "hedonistic mundanization" in process among Western elites family life at least since the Second World War (cf. Duarte 20o7). It consists in a systematic shifting from former grave consideration of family relatedness towards a lighter, joyous one. The analysis of family photographic archives elicits an ever growing prevalence of smiling faces - rather rare in former periods. But, then, this is a process similar and concomitant to what happens in most contexts of Christian religious contemporary culture. 
of palliative care are frank communication between the multi-professional health team, the patients and their family members, aiming for a death accepted by all the social actors involved in the care. According to the palliative viewpoint, the patient should control his or her own death process, with support from the professionals, who must provide care for the patient's "bio-psycho-social-spiritual" totality and that of his family members, with the purpose of constructing a trajectory leading to the final scene. It is about producing a peaceful, controlled and socially-accepted death - preferably, inthe patient's own home.

Palliative care - or the Hospice project - emerged in the late 196os, in the United Kingdom and the United States. Both propositions had a strong religious tone - in the English case, with the Christian influence of Cicely Saunders, pioneer of the "dying well" cause, who postulated the existence of "total pain", justifying care directed at the "totality" of the patient and his family and social circle. In the American project there is a Neo-Romantic emphasis, springing from the New Age movement, which is critical of technology and values nature, perceiving life as a flow encompassing the unique, singular individual whose interiority is seen as the locus of his truth (Magnani 2000; Green 2008). In this sense, moral and spiritual values become part of health professionals' cosmology and begin to influence their care practices.

In palliative care, family and family members are characters of extreme relevance, as it is a case of producing a "good death", which is socially visible and accepted - characteristics opposed to what Ariès (1977; 2003) called "the hiding of the death process", and Illich (1975) described as expropriation of one's own death.

In each context where it is implemented, the palliativist model takes on a specific form. Thus, in France, emphasis is given to psychological/psychoanalytical care, concerning end of life creation, both for the patient and for his family members and the health care professionals. The search for the meaning of life, disease and death is encouraged by the team, as is the creation and expression of an autobiographical report (Hennezel 1995; McNamara 2001). In the US there is stress on the production of a personalized death, in "your own way" (Byock1997). Anglo-Saxon countries present the idea of resolving issues such as material ones (documents, property), affective ones (conflict pacification) and emotional ones (acceptance of end of life), in order to achieve the "good death".

The English model also advocates a specific institution, which is distinct from a hospital or nursing unit; the "hospice", widespread since the AIDS epidemic due to its focus on patient needs as opposed to the hospital's rationalized logic. In this sense, care must be directed toward fulfilling the patient's wishes, on his own terms, with autonomy as a priority.

In Brazil, the specialization emerged in the late 1980s, out of the exclusive initiative of professionals from the National Cancer Institute, who were concerned about the neglect and suffering of patients diagnosed as having "run out of therapeutic possibilities". In 1991, a hospital was founded in the city of Rio de Janeiro, specifically targeting these types of patients: Cancer Hospital IV, belonging to the National Cancer Institute. From then onwards, other units were established throughout the country, with different care modalities; ambulatory, home care and/or hospital admission, when necessary, in order to control possible complications. In Brazil, there is only one public institution that functions according to the English hospice model: the Palliative Care Hostel, belonging to the Municipal Civil Servant Hospital in the city of São Paulo, inaugurated in 2004 .

Brazilian public palliative care contains a religious element that is even stronger than the original Anglo-Saxon models, consistent with the dominant system of belief in the country (even if supposedly inconsistent with the rationalized university training of the professionals). The doctors, psychologists, nurses and social workers who constituted the first teams at Cancer Hospital IV were, for the most part, spiritualists. The training of new specialists included specific instruction about the "spiritual care" category, considered fundamental within the viewpoint for the production of a "good 
death" (Menezes 2004). In interviews with more than twenty doctors in the cities of São Paulo and Rio de Janeiro, only two considered themselves to have no religion. The significant majority stated that they believed in the existence of spirits and in the possibility of life in another time or plane. It is worth noting that this type of discourse was independent of the professional's religious affiliation. For many interviewees, apart from the spirits, "energy", a very important category when dealing with the monitoring of the death process, could be donated or received, both by living persons and by spirits (see, on New Age current tendencies in Brazil, Steil 2001).For the interviewees, that energy is alive, apt to connect all the people who share responsibilities in the process of dying.

Criticism of an excessive use of technology, allied with the preeminence of religious values in palliative care, led to the production and implementation of different techniques for the creation of mourning and saying farewell to life, in various contexts. New professional categories were created to soothe fears of death, such as "midwives for the dying" in the United States, or "spiritual careers" in other countries. "Nature" sounds (such as running water and birdsong) and music are used to calm the patient, or phrases are whispered by professionals into patients' ears, such as "go towards the light, free yourself" (Menezes 2009, 2011).

Visualization exercises are proposed to patients, such as the technique created and implemented in Brazilian public hospitals, in which the patient must imagine himself going through a dark tunnel until he reaches a place filled with light, before a bridge. The professional who is guiding the meditation tells the patient not to look back and to walk across the bridge to meet the open-armed Jesus Christ or, if this figure is rejected, a relative who has already died (Menezes 2011). According to one doctor who applies the exercise to her patients, the technique helps to soothe fears of death and, sometimes, steadies the pace of breathing, which indicates that tranquility is being produced in the patient. Although this doctor declares herself to be a Catholic, in difficult moments, such as situations involving the suffering of patients, she prays and "asks for help" from the energy of Yemanjá, goddess of the sea in Afro-Brazilian religious tradition.

Attributing responsibility to deceased relatives and believing in the presence of their spirits is recurrent among Brazilian palliativists, independently of professional category. After a meeting with the family members of patients at Cancer Hospital IV, all the professionals (psychologists, nurses, and doctors) came together to evaluate the meeting. One of the comments referred to the presence of many spirits in the room, who were believed to be relatives who could be "guardian angels" in the "passage" to the "other side". In a first visit to the Palliative Care Hospice in São Paulo, the researcher asked the two doctors who accompanied her how they had found such a beautiful and comfortable house. The professionals smiled and pointed to the ceiling, and one asked the researcher: "Can't you see?" On asking what she should be seeing, the anthropologist heard the answer: "The protective spirits, they're here." Then, the doctors explained that the ease with which they had found the house could only be explained by the intermediation of the higher spirits, among whom there were probably some deceased patients or their accompanying family members.

The dialogue took place throughout the visit, while the doctors introduced the researcher to patients, their family members and companions and, also, to professionals and volunteers. The conversation theme - the communion and help of spirits in the work of caring for patients - remained the same. At several moments, the phrase "we're one big family" was uttered, both by a doctor and by other people - not always health professionals, as was the case with a security guard. The idea is that, in death, every family should come together to help in the passage from earthly life to another plane. In this sense, the ties are maintained between the dead and the living, a conception expressed by another doctor: "when a patient dies, his family member (for example, a daughter or wife) often offers to volunteer to care for another patient. Thus, he continues to attend the Hospice." The palliativist's explanation is based on the idea of maintaining spiritual connections among all those who make up the "Hospice family". 
It configures a transgenerational family, which is not limited to blood ties but extends to those who share the "mission" - faced with reverence - of leading the patient to "another plane." A sense of family has a specific configuration for the social actors at the Hospice; it is linked to maintaining relational connections, on different spheres of existence, so as to reveal a negation of the rupture produced by death. It is, therefore, about a temporally-continuous image, "ritualized by separation from the body" (Stoll 2003:85). To this are added the characteristics of communion and sharing a mission, seen as sacred by all involved in the dying process. All are part of the same - sacred - family, with no distinctions of race/ ethnicity, social status or cultural capital. However, one difference is repeatedly mentioned; that of gender - "men don't look after people, they generally abandon them, while women, whether they are daughters, wives, lovers, friends, neighbors, or cousins, look after people and devote themselves to them...”. As an illustration, a nurse pointed out that few men remain working at the Hostel, while women stay there, even bringing their relatives on their days off to become acquainted with the institution and its proposal ${ }^{12}$.

The blend of religious references and family ties constitutes a supporting axis for the Hospice's work. Meanings are attributed to care, such as sacredness and devotion, preserving the value of the family and the connections between its members. In this context, maintaining the personal identity of the deceased is a crucial notion. The individual - as a central value - must remain, as must his relations. For this purpose, strategies and practices are created, such as the palliative care proposal. In this sense, health professionals are at the service of dissemination of religious values, of meanings for life, family and person. In contemporary Western culture, "death does not remove a person's identity or individuality, which continues to exist in the memory of those that remain" (Strathern 1992:64) ${ }^{13}$.

In tribal societies, where heritage from predecessors is paramount in the definition of personal identities, be it in a positive sense, through the assumption of a continuity with certain lineages or ancestors (Fortes 1970a), be it in a negative one, through denial of any continuity and a rigorous deletion of the memories of the dead ones, one always enters life explicitly immersed in the relational ether. In Western societies, this universal fact tends to be obliterated in favor of the individualized model of personhood (Dumont 1972), propelling people to an ideal autonomic path, a sense of monadic existence materialized in concepts of liberty, creativity and authenticity. The fact that the ideal is never attained does not deprive it of its cogency; quite the contrary, the impossibility to reach it tends to entail a sense of inadequacy and failure whenever one faces a relational reality that reasserts itself.

\section{Towards a keener awareness of transpersonal ties}

The sociological perception of such a phenomenon is still very dim. The individualistic and disenchanted conventions concerning the phenomenology of human existence in modern Western societies are inextricable from the most basic "realistic" and "naturalistic" condition of its cosmology. The world is constituted by discrete pieces of matter, driven by discrete energies and observable by discrete sciences which paste here and there the amassed knowledge into models sufficiently structured so as to allow for technological advances and to further research into ever broadening frontiers. Human life came to be submitted to this mechanical scheme very early, and the whole of biomedicine is engaged in understanding the functioning of that machine, suffused with varying doses of a vitalist, romantic science.

12 Palliative care, originally, was a basically feminine specialization and, in recent years, has seen a trend towards male professionals joining the practice (Menezes, Heilborn 2007)

13 "Based on the premise that the English see the person as unique, the relations in which he is inserted contribute towards his individual history. But the person is also distinct from his relations. It is precisely because individual agents are conceived as having an existence apart from their relations that, after death, they can remain as they were" (Strathern 1992: 65). In other cultures, death determines a deconception process of the individual by the social group, with the dead person's name being erased, in a process of depersonalization: "When life ends - when the person is no longer active in his relations with others - those who related with the deceased person must alter the relation. If this does not happen, the dead person continues to influence the living" (Strathern 1992: 64). 
The human sciences eventually emerged thanks to the sundry reactions to mechanist cosmology concocted during the $19^{\text {th }}$ Century. Anthropology inherited a particularly intense disposition to discuss and relativize Western cosmology, instructed as it has been by comparative knowledge about other cultures, other ways of conceiving human existence and its wide force of invention. Relatedness is paramount in that knowledge, as a precondition of any humanity, and the intensity of the relations entertained among all sorts of persons, relatives and neighbors, allies and enemies, living and dead, mundane and spiritual, human and animal, is the focus of our interest in the discussion of the transpersonal dimensions. The old and ambiguous notion of ether, still invoked by Sir Isaac Newton in his first theories about gravity and now buried as an "obsolete scientific theory", may well summarize the intrinsic homology between a number of expressions equally devoted to describe that universal medium of relatedness: participation, embeddedness, belonging, mutuality, interdependence, solidarity, continued identity, sympathy ${ }^{14}$.

These categories in fact extend to the field of the relation among people (and homologous animated entities) a deep conscience of anthropological thought concerning a more universal ether, one that was masterly synthesized by Mauss around the notion of mana (Mauss, Hubert 1973) and reorganized by Lévi-

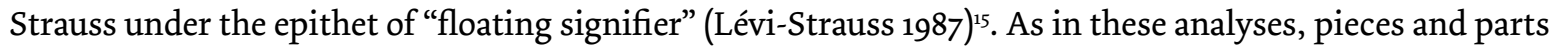
cannot mean anything except as a result of a general flow and abundance of meaning; as primordial as language itself, as encompassing as a cosmic vault.

We offer here some information about the ways in which the general phenomenon takes place in certain levels of Brazilian society. Some features are indistinguishable from other cultural areas around the world. Others may be more specific, at least in comparison with other Western or modern societies: the widespread prevalence of a sense of lived connectedness to family nebulae, be it under a religious or a lay guise; the existence of religious traditions of a family cult, and of analogous lay trends among cultivated upper-classes ${ }^{16}$.

It might remain to be ascertained how general certain traits here described may be, such as different gender emphases in transpersonal belongingin ordinary and critical situations or different broad cultural emphases in religious (or spiritual) dimensions of life. In any case, only further comparative investments concerning such experiences of an extended self in modern societies may bring sufficient light to one of the most profound, exciting and challenging dimensions of human social experience: its embeddedness in transpersonal relations.

Received: November $23^{\text {th }}$ 2016; Approved: February $22^{\text {th }} 2017$

\footnotetext{
14 Bruno Latour employs "ether" to deride what he characterizes as an inconvenient accent on an encompassing, holistic, condition, above or beyond flat interactions and associations (2005: 47); which is exactly what renders the term so strategically adequate for our purposes here.

15 These analyses allowed to see in a new light a vast set of questions hovering over Western self-consciousness since the $18^{\text {th }}$ Century and conflated in the category of "influence". Amorous and political, criminal and economic, religious and familial, it remained a typical mana like notion, still imperceptibly present in our ordinary usage to describe all transpersonal (and trans-cosmic) currents and flows.

16 Kevin Christiano (2000) describes the emergence of what he calls 'domestic Christianity' in his analysis of North American Christianity in the 19 th century, involving a radical sacralization of intra-domestic life in Protestant milieus. He emphasizes in the same sense the intensity of the articulation between family and religion in the commemoration of Thanksgiving Day in the USA.
} 


\section{References}

ABRAHAM, Nicolas. 1987. L'écorce et le noyau. Paris: Flammarion.

ARIÈS, Philippe. 1977. O homem diante da morte. Rio de Janeiro: Francisco Alves.

. 2003. História da morte no Ocidente.Rio de Janeiro: Ediouro.

AUBRÉE, Marion, LAPLANTINE, François. 1990. La table, le livre et les esprits: naissance, évolution et actualité du Mouvement Social Spirite entre France et Brésil. Paris: Éditions Jean-Claude Lattès.

BERGER, Peter. 2001. "A dessecularização do mundo: uma visão global”. Religião e Sociedade, 21(1):9-23.

BIRMAN, Patricia, LEITE, Márcia P. 2000. "Whatever happened to what used to be the largest catholic country in the world?" Daedalus,129(2): 271-90.

BYOCK, Ira. 1997. Dying well. Peace and possibilities at the end of life. New York: Riverhead Books.

CARSTEN, Janet. 2000. Cultures of relatedness. New approaches to the study of kinship. Cambridge: Cambridge University Press.

CHRISTIANO, Kevin J. 2000. "Religion and the family in modern American culture". In: S.K. Houseknecht \& J.G. Pankhurst (eds.), Family, religion, and social change in diverse societies. Oxford: Oxford University Press.pp. 43-78.

DAMATTA, Roberto. 1983. Carnavals, bandits et héros: ambiguités de la société brésilienne. Paris: Seuil.

DUARTE, Luiz F. D. 2007. “The Home Sanctuary. Personhood, Family and Religiosity”. Religião e Sociedade, vol. 3 no.se (special edition), URL: http://socialsciences.scielo.org/scielo.php?script=sci_arttext\&pid=S010085872006000200003\&lng=en\&nrm=iso.Accessed on May 14th, 2013.

DUARTE, Luiz F. D. 2011. "Geração, Fratria e Gênero: um estudo do mandato transgeracional e subjetivação". Trivium. Estudos Interdisciplinares, III (I), URL: http://www.uva.br/trivium/edicoes/edicao-i-ano-iii/artigostematicos/1-geracao-fratria-e-genero-um-estudo-de-mandato-transgeracional-e-subjetivacao-diferencial.pdf. Accessed on May 14th, 2013.

DUMONT, Louis. 1972. Homo hierarchicus - The caste system and its implications. London: Palladin.

DURKHEIM, Émile. 1953. Sociology and philosophy. London: Cohen and West.

. 1968. Les formes elémentaires de la vie religieuse. Paris: PUF.

FINAMORI, Sabrina. 2012. Os sentidos da paternidade: dos 'pais desconhecidos' ao exame de DNA. Dissertação.

Universidade Estadual de Campinas. Campinas.

FORTES, Meyer 1970a. "Pietas in ancestor worship". In: Meyer Fortes (ed.), Time and social structure and other essays. New York: Humanities Press. pp. 164-200.

. 1970b. "The structure of unilineal descent groups".In: Meyer Fortes (ed.), Time and Social Structure and other essays. New York: Humanities Press.pp. 67-95.

GELL, Alfred. 1998. Art and agency: an anthropological theory. Oxford: Clarendon Press.

HARTELIUS, Glenn; FRIEDMAN, Harris; ANDREESCU, Adrian.2013. Transpersonal studies. URL:http:// academia.edu/1592588/Transpersonal_Studies. Accessed on June 3oth 2013

GREEN, James W. 2008. The anthropology of modern dying. Philadelphia: University of Pennsylvania Press. HEILBORN, Maria Luiza. 2004. Dois é par: gênero e identidade sexual em contexto igualitário. Rio de Janeiro: Editora Garamond.

HENNEZEL, Marie. 1995. La mort intime. Paris: Robert Laffont.

ILLICH, Ivan. 1975. A expropriação da saúde. Nêmesis da medicina. Rio de Janeiro: Nova Fronteira.

LATOUR, Bruno. 2005. Reassembling the social: an introduction to actor-network-theory. Oxford: Oxford University Press.

LÉVY-BRUHL, Lucien.1985. How natives think. Princeton: Princeton University Press.

LÉVI-STRAUSS, Claude. 1987. Introduction to the work of Marcel Mauss. London: Routledge \& Kegan Paul. LINS DE BARROS, Myriam M. 1987. Autoridade e afeto. Rio de Janeiro: Zahar. 
LOMNITZ, Larissa A.; PEREZ-LIZAUR, Marisol. 1987. A Mexican elite family, 1820-1980. Kinship, class, and culture. Princeton: Princeton University Press.

MAÎTRE, Jacques. 1996. L'orpheline de la Bérésina - Thérèse de Lisieux (1873-1897) - Essai de psychanalyse sociohistorique. Paris: Les Éditions du CERF.

MAGGIE, Yvonne. 1992. Medo do Feitiço: Relações Entre Magia e Poder no Brasil. Rio de Janeiro: Ministério da Justiça.

MAGNANI, José Guilherme. 200o. O Brasil da Nova Era. Rio de Janeiro: Jorge Zahar.

MAUSS, Marcel. 1973. “Une catégorie de l'esprit humain: la notion de personne, celle de 'moi”. In: M.Mauss (ed.), Sociologie et anthropologie. Paris: PUF. pp.333-362.

MAUSS, Marcel; HUBERT, Henri. 1973. “Esquisse d'une théorie de la magie”. In: M. Mauss (ed.), Sociologie et anthropologie. Paris: PUF.pp.3-141.

MAZUR, Evangelina. 2006. "Família e laços familiares em um contexto espiritualista”. In: Luiz Fernando Dias Duarte et al. (eds.), Familia e religião. Rio de Janeiro: ContraCapa.pp.151-68.

MCNAMARA, Beverly. 2001. Fragile lives. Death, dying and care. Buckingham, Philadelphia: Open University Press.

MENEZES, Rachel A. 2004. Em busca da boa morte. Antropologia dos cuidados paliativos. Rio de Janeiro: Garamond / Fiocruz.

MENEZES, Rachel A. 2006. "Religiosidade e interpretação da morte”. Religião \& Sociedade, 26-1, pp. 174-197. MENEZES, Rachel A. 2009. "Preparação para a morte: entre religião, medicina e psicologia”. In: Edlaine Campos Gomes (ed.), Dinâmicas contemporâneas do fenômeno religioso na sociedade brasileira. Aparecida: Ideias \& Letras, pp. 53-73.

MENEZES, Rachel A. 2011. "Notas sobre a experiência de 'quase-morte': interpretações e sentidos”. In: Maria Claudia Coelho, Claudia Barcellos Rezende (eds.), Cultura e sentimentos. Ensaios em antropologia das emoções. Rio de Janeiro: Contracapa, pp. 143-167.

MENEZES, Rachel A., HEILBORN, Maria Luiza. 2007. "A inflexão de gênero na construção de uma nova especialidade médica”. Revista Estudos Feministas, 15-3, pp. 563-580.

MORSE, Richard M. 1998. O espelho de Próspero: cultura e ideias nas Américas. São Paulo: Companhia das Letras. MUSIL, Robert. 2001 [1906]. The confusions of young Törless. London: Penguin Classics.

PÁLSSON, Gísli. 2012. "Decode me! Anthropology and personal genomics”. CurrentAnthropology, 53(S5): S185-S195. http://www.jstor.org/stable/10.1086/662291. Accessed on May 14th, 2013

PINA CABRAL, João de. 2003. O homem na familia. Cinco ensaios de antropologia. Lisboa: Imprensa de Ciências Sociais.

POLANYI, Karl. 1957.The great transformation: the political and economic origins of our time. Boston: Beacon. RODRIGUES, R. Nina. 2007 [1896-7]. O animismo fetichista dos negros baianos. [facsimile edition; Yvonne

Maggie and Peter Fry (eds.)]. Rio de Janeiro: Fundação Biblioteca Nacional/UFRJ Editora.

SAHLINS, Marshall. 2011. "What kinship is”. Journal of the Royal Anthropological Institute, 17: 2-19. . 2013. What kinship is - and is not. Chicago: University of Chicago Press.

SALEM, Tania. 2007. O casal grávido. Disposições e dilemas da parceria igualitária. Rio de Janeiro: Editora FGV. SINGLY, François de. 2002. Être soi d'un âge à l'autre: famille et individualisation. Paris: L'Harmattan. SMITH, Adam. 1982. The theory of the moral sentiments. Indianapolis, Indiana: Liberty Press. STEIL, Carlos. 2001. "Pluralismo, modernidade e tradição: transformações do campo religioso." CienciasSociales y Religión / Ciências Sociais e Religião, 3(3): 115-29.

STEIL, Carlos. 2006. "Os demônios geracionais. A herança dos antepassados em um contexto católico carismático”.In: Luiz F. Dias Duarte et al. (orgs.), Familia e religião. Rio de Janeiro: ContraCapa. pp. 219239. 
STOLL, Sandra J. 2003. Espiritismo à brasileira. São Paulo, Curitiba: EdUSP, Orion.

STRATHERN, Marilyn. 1988. The gender of the gift: problems with women and problems with society in Melanesia. Berkeley / Los Angeles / London: University of California Press.

STRATHERN, Marilyn. 1992. Afternature: English kinship in the late twentieth century. Cambridge: Cambridge University Press.

VELHO, Gilberto.1991. "Indivíduo e religião na cultura brasileira". Novos Estudos -CEBRAP, 31:21-29. . 2001. "Família e parentesco no Brasil contemporâneo: individualismo e projetos no universo de camadas médias". Interseções. Revista de Estudos Interdisciplinares,3(2): 45- 52. . 1998. Nobres \& anjos: um estudo de tóxicos e hierarquia. Rio de Janeiro: Ed. Fundação Getúlio Vargas.

YANAGISAKO, Sylvia. 1979. "Patriarchal desire: law and sentiments of succession in Italian capitalist

families elites". In: João de Pina-Cabral, Antónia Pedroso de Lima (eds.), Choice, leadership and succession. New York: Berg. pp. 53-72.

Luiz Fernando Dias Duarte

National Museum, Federal University of Rio de Janeiro

E-mail: Ifdduarte@uol.com.br

Rachel Menezes Aisengart

Institute of Collective Health Studies, Federal University of Rio de Janeiro

E-mail: raisengartm@terra.com.br 